\title{
PENERAPAN METODE ELEKTROKIMIA UNTUK PENURUNAN CHEMICAL OXYGEN DEMAND (COD) DAN TOTAL SUSPENDED SOLID (TSS) LIMBAH CAIR INDUSTRI TAHU
}

\author{
APPLICATION OF ELECTROCHEMICAL METHODS \\ FOR DECREASING OF CHEMICAL OXYGEN DEMAND (COD) AND TOTAL \\ SUSPENDED SOLID (TSS) OF TOFU INDUSTRIAL WASTEWATER
}

\author{
Suyata*, Irmanto, dan Undri Rastuti \\ Jurusan Kimia, Fakultas MIPA Universitas Jenderal Soedirman \\ *email: suyatab@gmail.com
}

\begin{abstract}
ABSTRAK
Limbah cair industri tahu memiliki nilai COD dan TSS yang tinggi, apabila dibuang ke badan perairan akan menyebabkan pencemaran lingkungan. Oleh karena itu, perlu dilakukan penurunan nilai COD dan TSS limbah cair industri tahu tersebut sebelum dibuang ke badan perairan. Penurunan nilai COD dan TSS limbah cair industri tahu dapat dilakukan menggunakan metode elektrokimia. Penelitian ini bertujuan untuk mengetahui pengaruh voltase, jarak elektroda, $\mathrm{pH}$, dan waktu elektrolisis terhadap penurunan nilai COD dan TSS limbah cair industri tahu. Eksperimen dilakukan dengan mengelektrolisis limbah cair industri tahu menggunakan anoda $\mathrm{PbO}_{2}$ dan katoda $\mathrm{Pb}$. Hasil penelitian menunjukkan bahwa dibawah kondisi optimum pada voltase $12 \mathrm{~V}$, jarak elektroda $1 \mathrm{~cm}, \mathrm{pH}$ 1 dan waktu elektrolisis selama 120 menit, penurunan nilai COD dan TSS mencapai $96,33 \%$ dan $87,87 \%$
\end{abstract}

Kata kunci : COD, limbah cair industri tahu, TSS

\begin{abstract}
Tofu industrial wastewater has high COD and TSS level, which it cause an environmental pollution. Therefore, it is necessary to decrease the value of COD and TSS of tofu industrial wastewater before discharge into the water body. Decreasing of COD and TSS values can be carried out using an electrochemical method. The purpose of this research was to determine the effect of potential, electrode distance, $\mathrm{pH}$, and time to decrease of COD and TSS value of the tofu industrial wastewater. The experiment has been performed by electrolysis tofu industrial wastewater using $\mathrm{PbO}_{2}$ as anode and $\mathrm{Pb}$ as cathode. The result of the research showed that under the optimum conditions of $12 \mathrm{~V}$ voltage, $1 \mathrm{~cm}$ electrode distance, $\mathrm{pH}$ 1, and electrolysis time of 120 minutes, decreasing COD and TSS of $96.33 \%$ and $87.87 \%$ respectively.
\end{abstract}

Keywords : COD, TSS, tofu industrial wastewater

\section{PENDAHULUAN}

Limbah cair industri tahu berasal dari air bekas pencucian kedelai, perendaman kedelai, air bekas pembuatan tahu, dan air bekas perendaman tahu.
Limbah cair tersebut mengandung senyawa organik, jika langsung dibuang ke badan perairan akan menimbulkan pencemaran lingkungan. 
Mikroorganisme aerob dalam air yang berfungsi sebagai perombak (decomposer) senyawa organik hanya dapat menjalankan fungsinya jika terdapat oksigen yang cukup. Jika oksigen yang tersedia tidak mencukupi jumlah yang dibutuhkan maka oksidasi senyawa organik menjadi terhambat atau hanya sampai pada tahap pembusukan. Semakin banyak oksigen yang dibutuhkan untuk mengoksidasi senyawa organik akan menyebabkan kandungan oksigen dalam badan perairan berkurang. Dampaknya adalah kematian biota perairan. (Suharto, 2011)

Indikator tingginya kadar senyawa organik dalam limbah cair industri tahu adalah tingginya nilai COD dan TSS limbah cair tersebut. Oleh karena itu, untuk menurunkan nilai COD dan TSS limbah cair industri tahu tersebut perlu dilakukan penguraian senyawa organik yang terkandung dalam limbah sebelum dibuang ke badan perairan. Berbagai metode telah direkomendasikan untuk penurunan nilai COD dan TSS limbah cair industri tahu, namun metode-metode tersebut tidak efektif dan memerlukan biaya yang tinggi. Oleh sebab itu, sebagian besar industri tahu membuang limbah ke badan perairan tanpa pengolahan terlebih dahulu.

Metode elektrokimia memiliki keunggulan untuk pengolahan limbah cair organik dibandingkan dengan metodemetode lain. Kelebihan metode elektrokimia adalah : biaya operasional yang rendah sehingga lebih ekonomis, menghasilkan produk yang ramah lingkungan yaitu berupa $\mathrm{CO}_{2}$ dan $\mathrm{H}_{2} \mathrm{O}$, tidak menghasilkan limbah baru, berlangsung pada suhu rendah, dan efektif. (Comninellis, 1994; Chen et al., 2013; Suharto , 2011, dan Kapalka et al., 2009).

Salah satu faktor yang menentukan keberhasilan oksidasi senyawa organik menggunakan metode elektrokimia adalah material elektroda yang digunakan.
Berdasarkan sifat $\mathrm{PbO}_{2} / \mathrm{Pb}$ yang dapat menghantarkan arus, tahan terhadap korosi, mempunyai resistensi yang lebih baik dibandingkan elektroda lain baik dalam kondisi asam maupun basa, dan bersifat inert, maka material ini memenuhi syarat untuk dijadikan elektroda. (Klamklang et al , 2012).

$$
\text { Berdasarkan latar belakang }
$$

tersebut, telah dilakukan penelitian penerapan metode elektrokimia untuk penurunan nilai COD dan TSS limbah cair industri tahu dengan menggunakan elektroda $\mathrm{PbO}_{2} / \mathrm{Pb}$. Pada penelitian ini dipelajari pengaruh voltase, jarak elektroda, $\mathrm{pH}$, dan waktu elektrolisis terhadap persentase penurunan nilai COD dan TSS.

\section{METODE PENELITIAN}

\section{Alat dan Bahan}

Alat-alat yang digunakan adalah alatalat gelas, reaktor pengolahan limbah secara elektrokimia, adaptor, $\mathrm{PbO}_{2} / \mathrm{Pb}$ dari limbah sel aki sebagai elektroda. Bahan yang diperlukan adalah limbah cair industri tahu dari Desa Cilongok Kabupaten Banyumas, $\mathrm{Na}_{2} \mathrm{SO}_{4}, \mathrm{NaOH}$, $\mathrm{H}_{2} \mathrm{SO}_{4}, \mathrm{~K}_{2} \mathrm{Cr}_{2} \mathrm{O}_{7}, \mathrm{HgSO}_{4}, \mathrm{Ag}_{2} \mathrm{SO}_{4}$, ferro ammonium sulfat, indikator feroin, kertas Whatman nomor 40, akuades.

\section{Desain Alat}

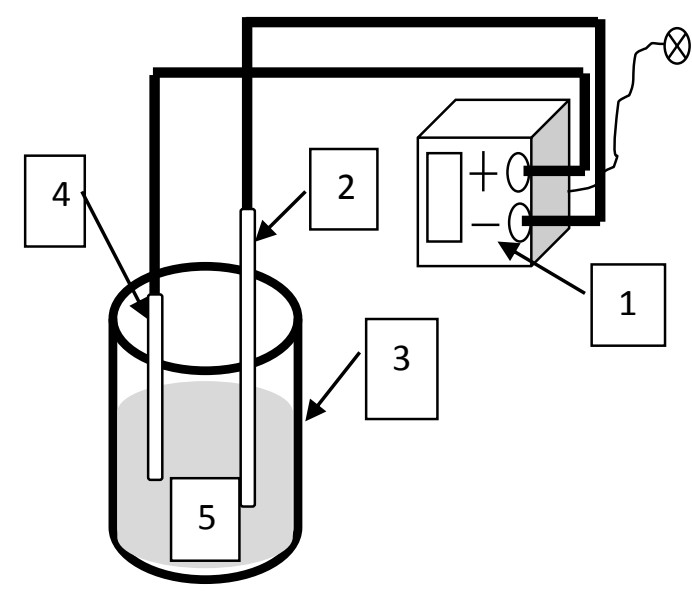

Gambar 1. Bagan Reaktor Elektrolisis

Reaktor elektrolisis terdiri dari adaptor (1), lempeng $\mathrm{Pb}$ sebagai katoda (2) 
yang ditempatkan sejajar dengan lempeng $\mathrm{PbO}_{2}$ sebagai anoda (4) dengan jarak $1 \mathrm{~cm}$. Rangkaian ini kemudian dipasangkan pada beker gelas $500 \mathrm{~mL}$ (3) sebagai tempat larutan sampel dan dihubungkan dengan sumber arus DC.

\section{Penentuan Pengaruh Voltase, Jarak Elektroda, pH, dan Waktu terhadap Penurunan Nilai COD dan TSS}

Limbah cair industri tahu sebanyak $500 \mathrm{~mL}$ dimasukkan ke dalam reaktor, kemudian ditambahkan $0,71 \quad \mathrm{~g} \quad \mathrm{Na}_{2} \mathrm{SO}_{4}$ sebagai elektrolit. $\mathrm{pH}$ larutan diatur menggunakan $\mathrm{NaOH}$ dan atau $\mathrm{H}_{2} \mathrm{SO}_{4} 1 \mathrm{M}$. Lempeng $\mathrm{PbO}_{2}$ dan $\mathrm{Pb}$ dimasukkan ke dalam reaktor dengan jarak $1 \mathrm{~cm}$. Larutan dielektrolisis pada variasi waktu 0 sampai 120 menit dengan selang waktu 30 menit pada voltase $4 \mathrm{~V}$ dan rapat arus $9 \mathrm{~A} / \mathrm{dm}^{2}$. Nilai COD dan TSS ditentukan sebelum dan setelah elektrolisis. Dengan prosedur yang sama dilakukan untuk variasi voltase dari 4 sampai 12 Volt, variasi jarak elektroda 0,$5 ; 1 ; 1,5 \mathrm{~cm}$, dan variasi $\mathrm{pH} 1$, $3,5,7,9,11,13$.

\section{Analisis COD (APHA, 1995)}

Penentuan COD dilakukan dengan menggunakan metode titrasi iodometri. Akuades sebanyak $5 \mathrm{~mL}$ sebagai blanko dan $5 \mathrm{~mL}$ sampel dimasukkan ke dalam Erlenmeyer $250 \mathrm{~mL}$ ditambahkan $2,5 \mathrm{~mL}$ $\mathrm{K}_{2} \mathrm{Cr}_{2} \mathrm{O}_{7}-\mathrm{HgSO}_{4}$ dan $5 \mathrm{~mL} \mathrm{H}_{2} \mathrm{SO}_{4}-$ $\mathrm{Ag}_{2} \mathrm{SO}_{4}$. Ditutup, lalu dipanaskan selama 2 jam dalam oven pada suhu $150{ }^{\circ} \mathrm{C}$, didinginkan dan dibilas bagian tutupnya dengan $2 \mathrm{~mL}$ akuades. Ditambahkan $1 \mathrm{~mL}$ $\mathrm{H}_{2} \mathrm{SO}_{4}$ pekat dan 3 tetes indikator feroin. Kemudian dititrasi dengan larutan standar ferro ammonium sulfat $0,025 \mathrm{~N}$ sampai berwarna merah coklat. Kadar COD dapat dihitung dengan rumus :

$$
\operatorname{Kadar} \mathrm{COD}(\mathrm{ppm})=\frac{(\mathrm{A}-\mathrm{B}) \times \mathrm{N} \times 8000}{\mathrm{~mL} \text { sampel }}
$$

Keterangan :

$\mathrm{A}=\mathrm{mL}$ pentiter untuk blanko

$\mathrm{B}=\mathrm{mL}$ pentiter untuk sampel

$\mathrm{N}=$ normalitas $\mathrm{Na}_{2} \mathrm{~S}_{2} \mathrm{O}_{3}$

\section{Analisis TSS}

TSS ditentukan dengan metode Gravimetri (PUSARPEDAL, 1996). Sebanyak $100 \mathrm{~mL}$ akuades disaring dengan kertas Whatman nomor 40, kemudian kertas saring tersebut dipanaskan di dalam oven dengan suhu $105{ }^{\circ} \mathrm{C}$ selama 1 jam dan didinginkan dalam desikator selama 15 menit, lalu ditimbang berat awalnya (misalnya : $a$ gram). Diambil $100 \mathrm{~mL}$ sampel air limbah, disaring dengan menggunakan kertas saring yang telah diketahui beratnya, kemudian dikeringkan di dalam oven dengan suhu $105^{\circ} \mathrm{C}$ selama 1 jam. Selanjutnya didinginkan dalam desikator selama kurang lebih 15 menit, lalu ditimbang berat akhirnya (misalnya $: b$ gram). Kandungan total padatan tersuspensi dihitung dengan menggunakan rumus:

$$
T S S=(b-a) \times \frac{1000}{100} m g \cdot L^{-1}
$$

\section{HASIL DAN PEMBAHASAN}

Pada penelitian ini dilakukan pengolahan limbah cair industri tahu secara elektrokimia dengan memanfaatkan limbah sel aki sebagai elektroda. $\mathrm{PbO}_{2}$ sebagai anoda, $\mathrm{Pb}$ sebagai katoda, dan $\mathrm{Na}_{2} \mathrm{SO}_{4}$ sebagai elektrolit pendukung. Senyawa organik yang terdapat dalam limbah cair industri tahu akan dioksidasi di anoda. Sebagai indikator telah teroksidasinya senyawa organik dalam limbah cair industri tahu, dilakukan pengukuran nilai COD dan TSS sebelum dan setelah diolah secara elektrokimia.

\section{Pengaruh Voltase pada Proses Elektrolisis terhadap Nilai COD dan TSS}

Untuk mempelajari pengaruh voltase selama proses elektrolisis pada pengolahan limbah cair industri tahu secara elektrokimia, dilakukan variasi voltase dari 4 sampai dengan 12 volt. Elektrolisis dilakukan selama 30, 60, 90, dan 120 menit pada $\mathrm{pH}$ larutan 3 dan jarak 
elektroda $1 \mathrm{~cm}$. Nilai COD dan TSS Hasil penelitian dapat dilihat pada diukur sebelum dan setelah elektrolisis. Gambar 2 dan 3.

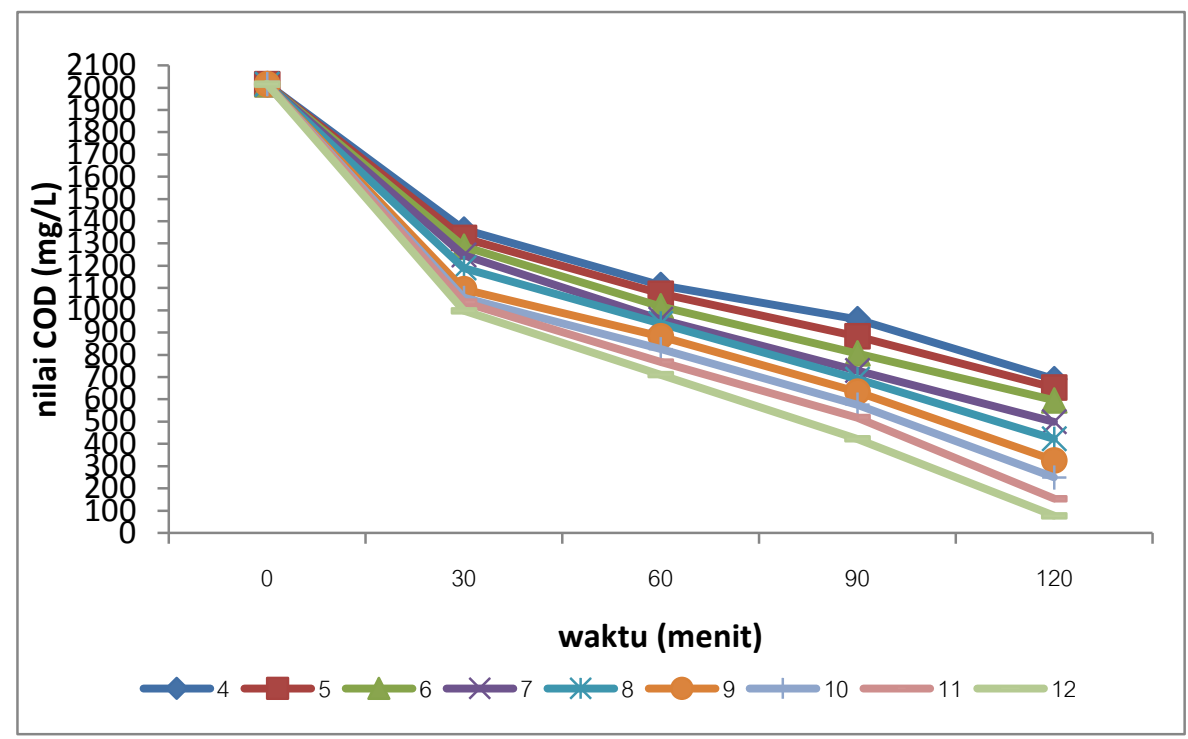

Gambar 2. Grafik hubungan antara variasi voltase dengan nilai COD, hasil elektrolisis limbah cair industri tahu, menggunakan elektroda $\mathrm{PbO}_{2} / \mathrm{Pb}$

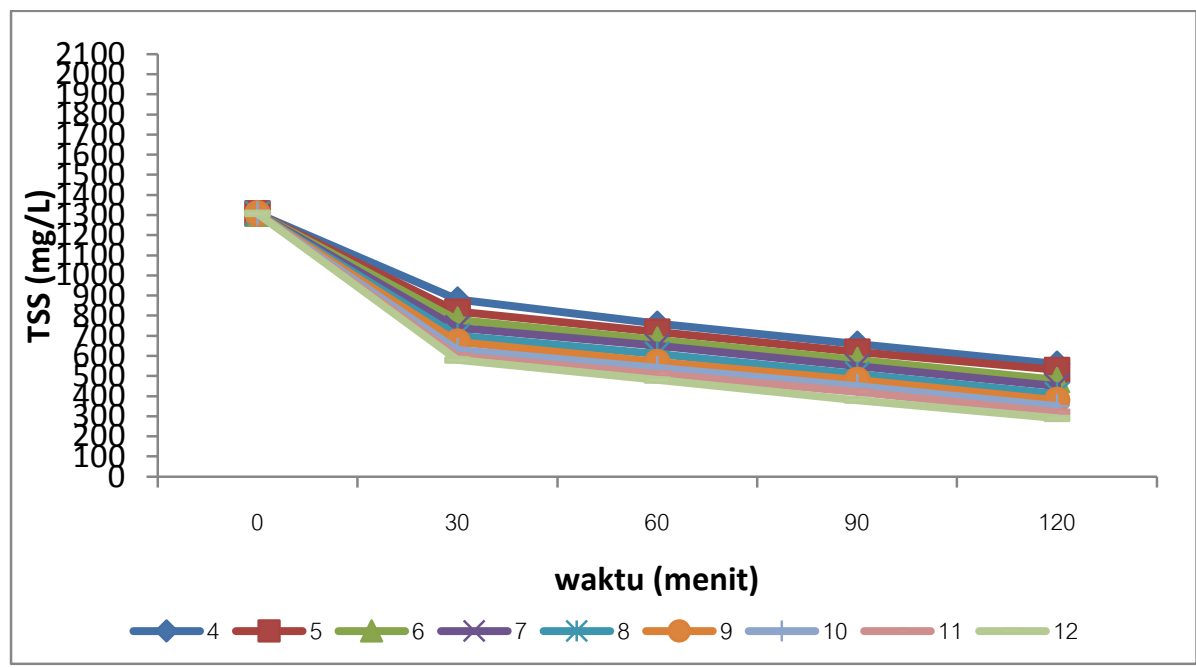

Gambar 3. Grafik hubungan antara variasi voltase dengan TSS, hasil elektrolisis limbah cair industri tahu, menggunakan elektroda $\mathrm{PbO}_{2} / \mathrm{Pb}$

Berdasarkan Gambar $\mathbf{2}$ dan $\mathbf{3}$ yang menyatakan bahwa voltase dapat dilihat bahwa penurunan nilai COD merupakan salah satu faktor yang dapat dan TSS meningkat dengan bertambahnya voltase. Hal ini disebabkan karena apabila voltase diperbesar maka reaksi reduksi dan oksidasi (redoks) akan semakin cepat terjadi. Semakin cepat reaksi redoks maka jumlah senyawa organik yang teroksidasi juga semakin banyak. Indikator banyaknya senyawa organik yang teroksidasi adalah semakin besar penurunan nilai COD dan TSS. Hal ini sesuai dengan dasar teori mempengaruhi proses elektrolisis (Klamklang et al., 2012).

Penurunan nilai COD dan TSS maksimum terjadi pada voltase 12 volt dengan waktu elektrolisis selama 120 menit. Nilai COD menjadi $76,98 \mathrm{mg} / \mathrm{L}$ dan TSS menjadi $290 \mathrm{mg} / \mathrm{L}$. Persentase penurunan nilai COD dan TSS berturutturut adalah $96,19 \%$ dan $77,83 \%$. Oleh 
karena itu, voltase optimum proses elektrolisis adalah 12 Volt.

\section{Pengaruh Jarak Elektroda pada Proses Elektrolisis terhadap Nilai COD dan TSS}

Pada penelitian ini dilakukan variasi jarak elektroda yaitu $0,5: 1 ; 1,5 \mathrm{~cm}$. Hasil penelitian seperti terlihat pada Gambar 4 dan 5. Berdasarkan hasil penelitian menunjukkan bahwa jarak elektroda mempengaruhi penurunan nilai COD dan TSS, dengan jarak elektroda optimum adalah $1 \mathrm{~cm}$.
Pada jarak elektroda optimum ini terjadi penurunan nilai COD dan TSS paling maksimum. Nilai COD turun menjadi $76,98 \mathrm{mg} / \mathrm{L}$ dan TSS turun menjadi $290 \mathrm{mg} / \mathrm{L}$. Persentase penurunan nilai COD dan TSS berturut-turut adalah 96,19\% dan 77,83\%. Pada jarak elektroda optimum, radikal $\mathrm{OH}$ yang dihasilkan selama proses elektrolisis berada di permukaan anoda $\mathrm{PbO}_{2}$ lebih banyak dan merata. Semakin banyak jumlah radikal $\mathrm{OH}$ di permukaan anoda $\mathrm{PbO}_{2}$, semakin banyak senyawa organik yang teroksidasi dan semakin besar penurunan nilai COD dan TSS.

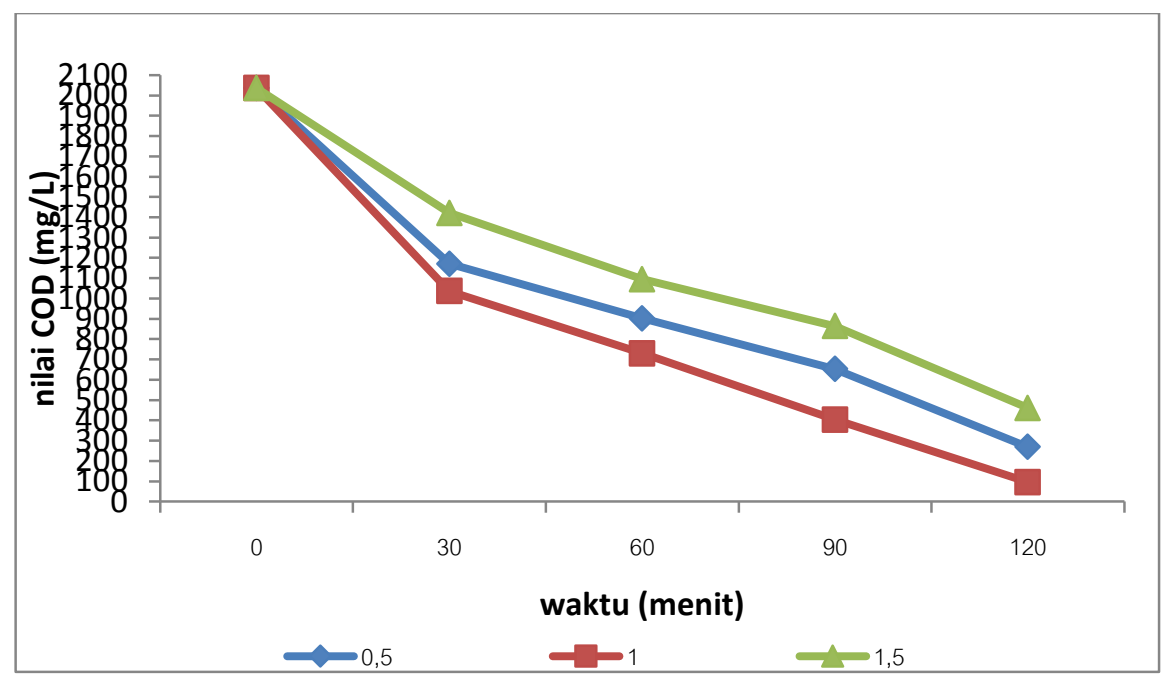

Gambar 4. Grafik hubungan antara variasi jarak elektroda dengan nilai COD, hasil elektrolisis limbah cair industri tahu, menggunakan elektroda $\mathrm{PbO}_{2} / \mathrm{Pb}$

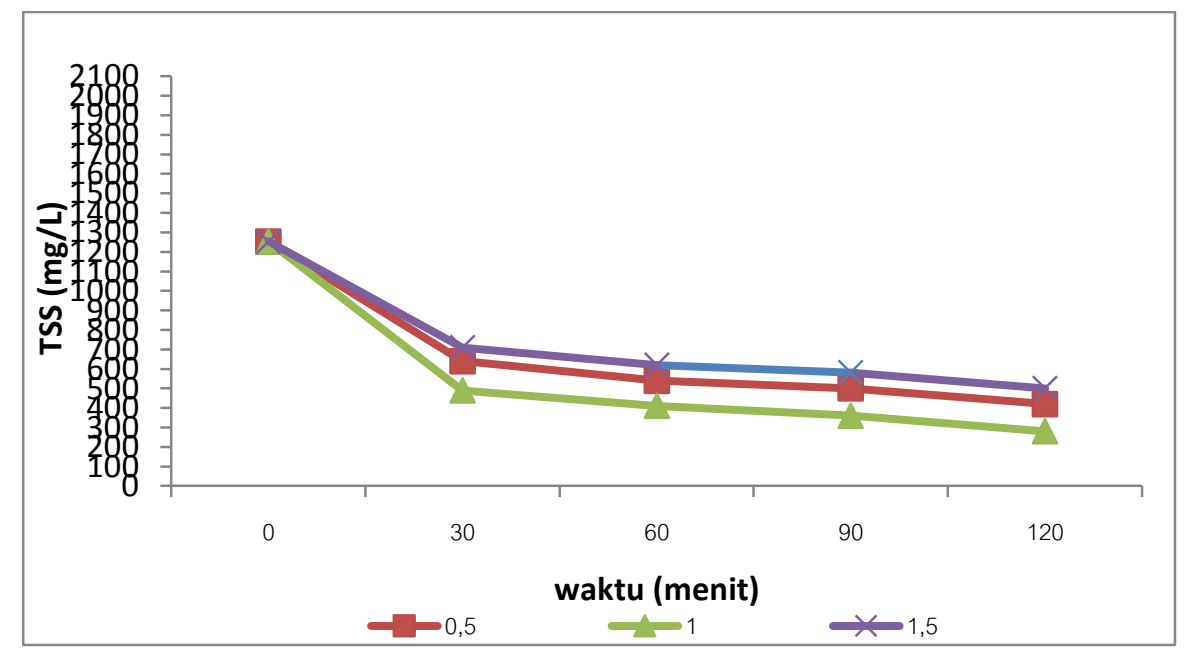

Gambar 5. Grafik hubungan antara variasi jarak elektroda dengan TSS, hasil elektrolisis limbah cair industri tahu, menggunakan elektroda $\mathrm{PbO}_{2} / \mathrm{Pb}$ 
Pengaruh pH Larutan pada Proses Elektrolisis terhadap Nilai COD dan TSS

Untuk mengetahui pengaruh $\mathrm{pH}$ terhadap penurunan nilai COD dan TSS dilakukan variasi $\mathrm{pH}$ pada $\mathrm{pH} 3 ; 5 ; 7 ; 9$; 11; dan 13. Hasil penelitian seperti terlihat pada Gambar 6 dan 7.

Gambar 6 dan 7 menunjukkan bahwa $\mathrm{pH}$ optimum dalam proses oksidasi senyawa organik limbah cair industri tahu adalah $\mathrm{pH}$ asam yaitu $\mathrm{pH} 1$. Nilai COD yaitu $96 \mathrm{mg} / \mathrm{L}$ dengan persentase penurunannya $96,33 \%$. Nilai TSS $310 \mathrm{mg} / \mathrm{L}$ dengan persentase penurunannya $87,87 \%$. Persentase penurunan nilai COD dan TSS limbah cair industri tahu dengan menggunakan metode elektrokimia ini lebih baik dibandingkan dengan menggunakan metode Multi Soil Layering dan juga sistem zeolit teraktivasi dan terimpregnasi $\mathrm{TiO}_{2}$. Persentase penurunan nilai COD dan TSS menggunakan metode Multi Soil Layering adalah $95,53 \%$ dan $78,62 \%$ (Irmanto dan Suyata, 2009). Persentase penurunan nilai
COD dan TSS menggunakan sistem zeolit teraktivasi dan terimpregnasi $\mathrm{TiO}_{2}$ adalah $89,92 \%$ dan $82,42 \% \%$ (Suyata dan Irmanto, 2009).

Penurunan nilai COD dan TSS maksimum terjadi pada suasana asam. Hal ini disebabkan karena jumlah $\mathrm{H}^{+}$yang terkandung dalam larutan lebih banyak. Jumlah $\mathrm{H}^{+}$sebanding dengan jumlah radikal $\mathrm{OH}$, sehingga menyebabkan oksidasi senyawa organik dalam limbah cair industri tahu menjadi lebih banyak dibandingkan dengan $\mathrm{pH}$ yang lebih besar.

Menurut Klamklang et al., 2012; Nava et al., 2008; Sala and Bouzan, 2012, reaksi oksidasi senyawa organik akibat aktivitas ${ }^{\circ} \mathrm{OH}$ adalah sebagai berikut:

$$
\begin{gathered}
\mathrm{PbO}_{2}[]+\mathrm{H}_{2} \mathrm{O} \longrightarrow \mathrm{PbO}_{2}\left[{ }^{\bullet} \mathrm{OH}\right]+\mathrm{H}^{+}+\mathrm{e}^{-} \\
\mathrm{R}+\left[^{\bullet} \mathrm{OH}\right] \longrightarrow \mathrm{R}^{\bullet}+\mathrm{H}^{+}+\mathrm{e}^{-} \\
\mathrm{R}^{\bullet}+\mathrm{H}^{+}+\mathrm{e}^{-} \longrightarrow \mathrm{CO}_{2}+\mathrm{CO}+\mathrm{H}_{2} \mathrm{O}
\end{gathered}
$$

dengan $\mathrm{R}$ adalah senyawa organik. Jika proses oksidasi berlangsung sempurna maka CO tidak akan terbentuk karena akan teroksidasi lebih lanjut menjadi $\mathrm{CO}_{2}$.

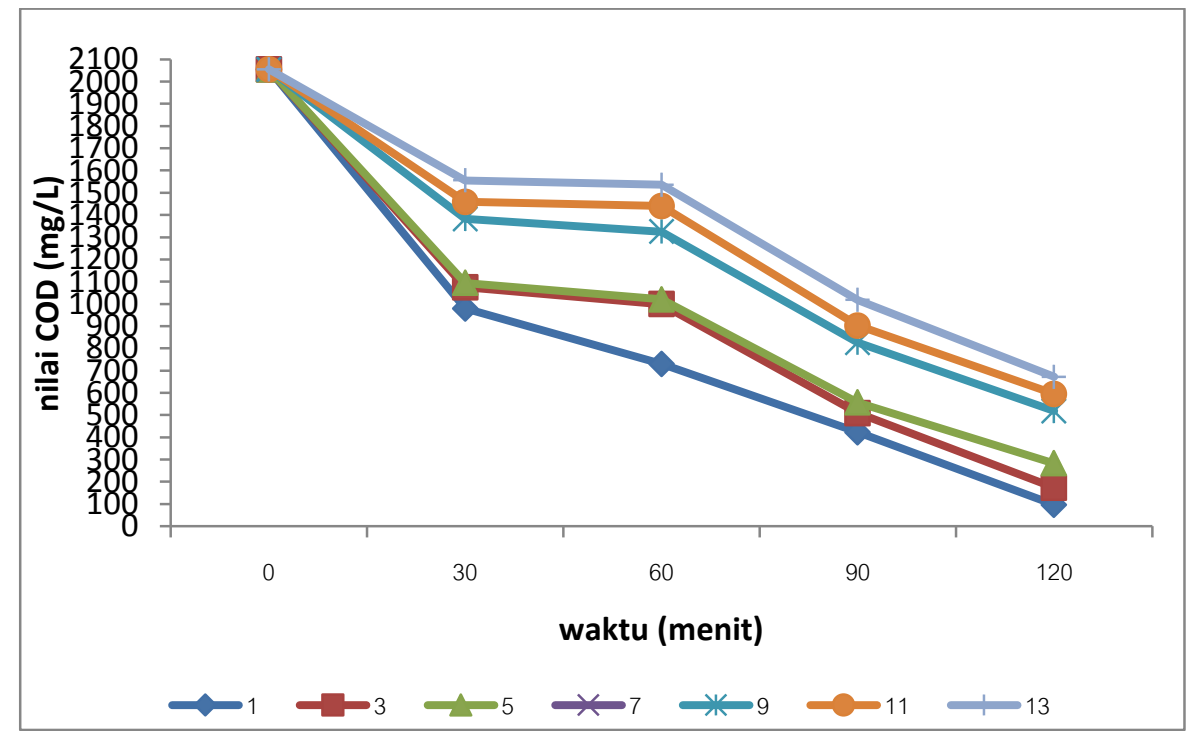

Gambar 6. Grafik hubungan antara variasi $\mathrm{pH}$ larutan dengan nilai COD, hasil elektrolisis limbah cair industri tahu, menggunakan elektroda $\mathrm{PbO}_{2} / \mathrm{Pb}$ 


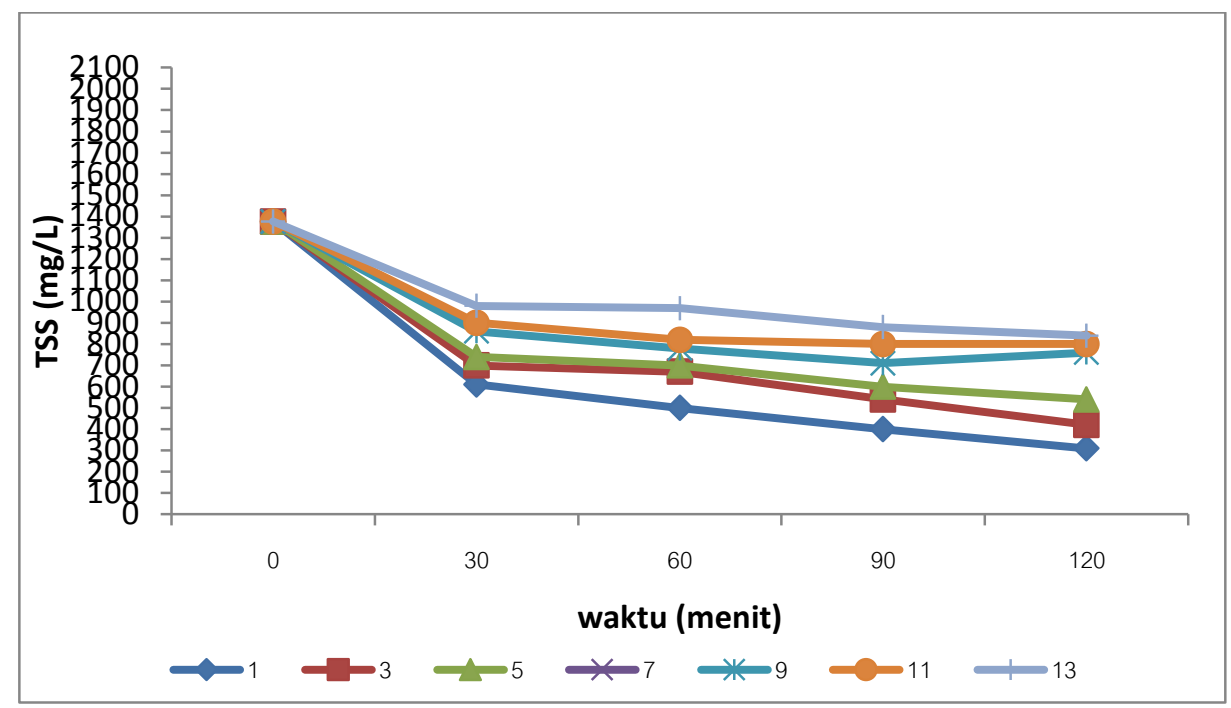

Gambar 7. Grafik hubungan antara variasi $\mathrm{pH}$ larutan dengan TSS, hasil elektrolisis limbah cair industri tahu, menggunakan elektroda $\mathrm{PbO}_{2} / \mathrm{Pb}$

\section{KESIMPULAN}

Berdasarkan hasil penelitian dapat disimpulkan bahwa dibawah kondisi optimum pada voltase $12 \mathrm{~V}$, jarak elektroda $1 \mathrm{~cm}, \mathrm{pH} 1$ dan waktu elektrolisis selama 120 menit, penurunan nilai COD dan TSS mencapai $96,33 \%$ dan $87,87 \%$

\section{DAFTAR PUSTAKA}

APHA, 1995, Standard Method for the Examination of Water and Wastewater, $19^{\text {th }}$ ed. American Public Health Association, Washington

Comninellis, C, 1994, Electrocatalysis in the Electrochemical Conversion of Organic Pollutants for Wastewater Treatment, Electrochimica Acta, Vol 39, No.11,pp. 1857-1862

Chen, X, G.Huang, and J. Wang, 2013, Electrochemical

Reduction/Oxidation in Treatment of Heavy Metal Wastewater, Journal of Metallurgical Engineering, Vol 2, No.4, pp. 161164

Irmanto dan Suyata, 2009, Pengolahan Limbah Cair Industri Tahu di Desa Kalisari Kecamatan Cilongok dengan Metode Multi Soil
Layering, Jurnal Ilmiah Kimia Molekul, Vol 4, No. 1, pp. 21-32

Kapalka, A, G. Foti, and C.Comninellis, 2009, Basic Principles of the Electrochemical Mineralization of Organic Pollutants for Wastewater Treatment, Journal of Applied Electrochemistry, Vol 40, No. 12, pp. 2203-2210

Klamklang, S, H. Vergnes, K. Pruksathorn, and S. Damronglerd, 2012, Electrochemical Incineration of Organic Pollutants for Wastewater Treatment : Past, Present and Prospect, In Tech, Croatia

Nava, J.L, M.A.Quiroz, and C.A.M. Huitle, 2008, Role of Electrode Material in Colour and COD Removal, Journal Mex.Chem.Soc, Vol 52, No. 4,pp. 249-255

PUSARPEDAL, 1996, Materi Ajar Pelatihan Analisis Kualitas Air dan Limbah Cair Tahap III, Pengendalian Dampak Lingkungan, Jakarta

Sala, M and M.C.G. Bouzan, 2012, Review Article Electrochemical Techniques in Textile Processes and Wastewater Treatment, International Journal of 
Penerapan Metode Elektrokimia untuk Penurunan...(Suyata, dkk)

Photoenergy, Vol 12, No. 10, pp. 112

Suharto, 2011, Limbah Kimia dalam Pencemaran Udara dan Air, ANDI, Yogyakarta

Suyata dan Irmanto, 2009, Penurunan TSS, BOD, dan COD Limbah Cair
Industri Tahu di Desa Cilongok

Kabupaten Banyumas Menggunakan Sistem Zeolit Teraktivasi dan Terimpregnasi $\mathrm{TiO}_{2}$, Jurnal Ilmiah Kimia Molekul, Vol 4, No. 2, pp. 83-93 